\title{
Growth/Differentiation Factor 11
}

National Cancer Institute

\section{Source}

National Cancer Institute. Growth/Differentiation Factor 11. NCI Thesaurus. Code C148355.

Growth/differentiation factor 11 (407 aa, $\sim 45 \mathrm{kDa}$ ) is encoded by the human GDF11 gene. This protein plays a role in patterning of mesodermal, neural and skeletal tissues during development. 